\title{
PENINGKATAN AKTIVITAS DAN PRESTASI BELAJAR SISWA MENGGUNAKAN MODEL PEMBELAJARAN PROJECT BASED LEARNING (PjBL) PADA LARUTAN ELEKTROLIT DAN NON-ELEKTROLIT KELAS X MIA 4 SMA NEGERI 4 SURAKARTA TAHUN PELAJARAN 2016/2017
}

\author{
Arini Miftakhul Jannah, Bakti Mulyani ${ }^{\star}$, dan Mohammad Masykuri \\ Program Studi Pendidikan Kimia, FKIP, Universitas Sebelas Maret, Surakarta, Indonesia \\ *Keperluan Korespondensi, telp: +6281280660500, email: baktimulyani@gmail.com
}

\begin{abstract}
ABSTRAK
Penelitian ini bertujuan untuk meningkatkan aktivitas dan prestasi belajar siswa kelas $X$ MIA 4 SMA Negeri 4 Surakarta tahun pelajaran 2016/2017 melalui penerapan model pembelajaran Project Based Learning (PjBL) pada materi larutan elektrolit dan non-elektrolit. Penelitan yang dilakukan merupakan penelitian tindakan kelas dan terdiri dari dua siklus.Setiap siklus terdapat empat tahap yaitu, perencanaan tindakan, pelaksanaan tindakan, observasi dan evaluasi serta refleksi.Subjek penelitian adalah X MIA 4 SMA Negeri 4 Surakarta tahun pelajaran 2016/2017. Penelitian ini menggunakan teknik analisis kualitatif. Data pada penelitian diperoleh melalui observasi, wawancara, kajian dokumen, angket dan tes. Hasil penelitian menunjukkan bahwa aktivitas belajar siswa dengan kategori aktif dan sangat aktif sebesar $67 \%$ pada siklus 1 menjadi $80 \%$ pada siklus 2, prestasi belajar siswa aspek pengetahuan dengan ketuntasan siswa sebesar $53 \%$ pada siklus 1 dan $77 \%$ pada siklus 2, ketercapaian aspek sikap pada siklus 1 sebesar $97 \%$, dan ketercapaian aspek keterampilan sebesar $100 \%$. Prestasi belajar aspek sikap dan keterampilan tidak dilakukan pada siklus 2. Kesimpulan dari penelitian ini adalah model pembelajaran $\mathrm{PjBL}$ dapat meningkatkan kemampuan aktivitas dan prestasi belajar siswa pada materi larutan elektrolit dan non-elektrolit kelas X MIA 4 SMA Negeri 4 Surakarta Tahun Pelajaran 2016/2017.
\end{abstract}

Kata kunci : Project Based Learning (PjBL), aktivitas belajar siswa, prestasi belajar, larutan elektrolit dan non-elektrolit.

\section{PENDAHULUAN}

Pendidikan merupakan salah satu faktor terpenting dalam berbangsa dan bernegara. Sumber daya manusia yang berkualitas sangat dipengaruhi oleh keberadaan pendidikan. Peran pendidikan menjadi vital dalam membentuk karakter dan kualitas sumber daya manusia di Indonesia.

Untuk mencapai tujuan tersebut, pemerintah melakukan berbagai upaya untuk meningkatkan kualitas pendidikan, salah satu upaya yang dilajukan pemerintah yaitu dengan cara mengembangkan kurikulum [1]. Kurikulum yang dikembangkan di Indonesia saat ini adalah kurikulum 2013.
Pembelajaran kimia yang sesuai dengan kurikulum 2013 menekankan pembelajaran yang melibatkan peserta didik (student centered learning) secara aktif, agar mereka mampu bereksplorasi untuk membentuk kompetensi yang unggul.

Pada kenyataannya, pembelajaran kimia di SMA N 4 Surakarta masih berpusat pada guru (Teacher Centered Learning) dan media pembelajaran yang digunakan masih belum inovatif. Guru belum memanfaatkan secara maksimal fasilitas sekolah yang disediakan seperti proyektor dan laboratorium kimia sehingga potensi peserta didik dan aktivitas siswa tidak berkembang meskipun siswa 
memiliki motivasi yang tinggi pada pelajaran kimia.

Berdasarkan wawancara yang dilakukan dengan guru diperoleh hasil aktivitas siswa di kelas $X$ MIA 4 cenderung pasif dan kurang responsif. Hasil angket prasiklus untuk aktivitas belajar siswa yang dilakukan di kelas $X$ MIA 4 menunjukkan bahwa $65 \%$ siswa yang memiliki aktivitas dengan kategori sangat aktif dan aktif.

Salah satu materi yang dianggap bermasalah oleh guru di kelas $X$ semester genap adalah materi larutan elektrolit dan non-elektrolit. Materi tersebut membutuhkan pemahaman konsep yang tinggi dan hafalan yang kuat serta pengalaman belajar yang nyata dan aplikatif. Siswa menganggap materi kimia bersifat teoritis dan hafalan merupakan materi yang abstrak. Hal ini disebabkan karena kimia memiliki perbendaharaan kata yang khusus, dimana mempelajari kimia sama seperti mempelajari bahasa yang baru [2]. Oleh karena itu, siswa membutuhkan pola belajar yang kreatif, inovatif dan aplikatif agar materi dapat diterima dan dipahami secara optimal.

Hasil dari kajian dokumen diperoleh rata-rata nilai ulangan harian siswa pada materi larutan elektrolit dan non-elektrolit tahun pelajaran 2015/2016 sebesar 67,88. Nilai tersebut masih dibawah rata-rata KKM yang ditetapkan yaitu 75 , sehingga pada tahun pelajaran 2016/2017 perlu diupayakan perbaikan agar terjadi peningkatan pada ulangan harian materi tersebut.

SMA N 4 Surakarta memiliki 7 kelas MIPA. Berdasarkan kajian dokumen diperoleh rata-rata nilai UAS Kimia kelas $X$ MIA semester 1 tahun pelajaran 2016/2017 bahwa rata-rata semua kelas masih dibawah KKM yang ditentukan sekolah yaitu 75 . Nilai rata-rata UAS kimia kelas X tahun pelajaran 2016/2017 disajikan dalam Tabel 1.

Berdasarkan data hasil nilai UAS kimia kelas $X$ tahun pelajaran 2016/2017 diperoleh hasil bahwa kelas X MIA 4 merupakan salah satu kelas yang memiliki rata-rata prestasi belajar paling rendah dibanding dengan kelas lain. Rendahnya prestasi belajar siswa kelas
$X$ MIA 4 menjadikan alasan kelas ini digunakan untuk penelitian.

Tabel 1. Nilai Rata-rata UAS Kimia kelas X MIA tahun pelajaran 2016/2017

\begin{tabular}{cc}
\hline Kelas & Nilai Rata-rata \\
\hline X MIA 1 & 71,18 \\
X MIA 2 & 69,68 \\
X MIA 3 & 66,78 \\
X MIA 4 & 64,08 \\
X MIA 5 & 70,94 \\
X MIA 6 & 71,79 \\
X MIA 7 & 67,83 \\
\hline
\end{tabular}

Salah satu upaya untuk meningkatkan aktivitas dan prestasi belajar siswa kelas X MIA 4 SMA N 4 Surakarta pada materi larutan elektrolit dan non-elekrolit digunakan model pembelajaran Project Based Learning (PjBL). PjBL adalah model pembelajaran yang menggunakan proyek sebagai inti pembelajaran. Model tersebut sangat penting untuk mening-katkan kualitas aktivitas siswa dan mengandung beberapa proses pem-belajaran yang berbeda [3]. Sintaks PjBL terdiri dari 6 tahap berikut, (1) penentuan pertanyaan mendasar, (2) menyusun perencanaan proyek, (3) menyusun jadwal, (4) memantau siswa dan kemajuan proyek, (5) penilaian hasil, (6) evaluasi pengalaman [4]. Model pembelajaran yang digunakan akan berhasil jika disertai dengan media pembelajaran yang menunjang. Media pembelajaran akan menumbuhkan interaksi multiarah antara guru dengan siswa yang lebih positif, sehingga pembelajaran akan ber-langsung efektif dan efisien.

Salah satu media pembelajaran yang dapat dikolaborasikan dengan model pembelajaran PjBL adalah Tekateki Silang (TTS). Model pembelajaran PjBL yang dilengkapi dengan media TTS merupakan salah satu upaya untuk meningkatkan aktivitas belajar dan prestasi belajar siswa. Media TTS dapat mengasosiasikan pembelajaran sebagai proses belajar dengan bermain game dan rekreasi serta meningkatkan kepercayaan diri siswa dalam hal kemampuan dan pemahaman mereka [5]. Media TTS tidak diberikan oleh guru melainkan 
siswa sendiri yang membuatnya. Pada pelaksanaannya, media TTS berguna untuk meninjau ulang (review) materimateri yang sudah disampaikan.

Penerapan model pembelajaran PjBL yang dikolaborasikan dengan media TTS diharapkan dapat meningkatkan aktivitas belajar dan prestasi belajar siswa pada materi larutan elektrolit dan non-elektrolit di kelas X MIA 4 SMA Negeri 4 Surakarta tahun pelajaran 2016/2017.

\section{METODE PENELITIAN}

Penelitian yang dilakukan merupakan Penelitian Tindakan Kelas (PTK). PTK bertujuan untuk memperbaiki berbagai persoalan nyata dan praktis dalam peningkatan mutu pembelajaran di kelas yang dialami langsung dalam interaksi antara guru dengan siswa yang sedang belajar [6].

Subjek penelitian adalah siswa kelas X MIA 4 semester genap SMA Negeri 4 Surakarta tahun pelajaran 2016/2017 dengan jumlah siswa 30 siswa yang terdiri dari 11 siswa laki-laki dan 19 siswa perempuan. Objek pnelitian adalah aktivitas belajar dan prestasi belajar siswa terhadap pembelajaran yang diterapkan pada materi larutan elektrolit dan non-elektrolit. Sumber data yang digunakan adalah guru dan siswa.

Teknik pengumpulan data yang digunakan dalam penelitian ini meliputi, tes, observasi, wawancara, kajian dokumen, dan angket. Teknis analisis data yang digunakan adalah analisis kualitatif yang mengacu pada analisis model Miles dan Huberman dengan komponen meliputi reduksi data, penyajian data, dan penarikan kesimpulan dan verifikasi [7].

Teknik untuk memeriksa validitas data adalah teknik triangulasi. Triangulasi merupakan teknik pengecekan data dari berbagai sumber dengan berbagai cara dan berbagai waktu biasanya menggunakan observasi, angket, dan wawancara [8].

\section{HASIL DAN PEMBAHASAN}

Pada awal tindakan dilakukan tahap wawancara, angket prasiklus dan kajian dokumen untuk mengetahui kondisi awal siswa. Data hasil wawancara dengan guru menunjukkan bahwa siswa kelas X MIA 4 SMA N 4 Surakarta memiliki aktivitas belajar siswa rendah. Hasil tes prasiklus aktivitas belajar siswa menunjukkan bahwa $65 \%$ siswa kelas X MIA 4 mempunyai kategoti aktif dan sangat aktif. Dari hasil kajian dokumen diperoleh bahwa rata-rata nilai siswa pada materi larutan elektrolit dan non-elektrolit tahun pelajaran 2015/2016 masih berada dibawah KKM yaitu 64,08.

\section{Siklus 1}

\section{a. Perencanaan Tindakan}

Pada tahap perencanaan tindakan siklus 1 peneliti dan guru melakukan kajian terhadap silabus mata pelajaran kimia. Silabus diperoleh dari guru dan dikaji kembali oleh peneliti. Silabus tersebut dijadikan dasar oleh peneliti untuk membuat rencana pelaksanaan pembelajaran (RPP). Kemudian dilakukan penyusunan instrumen aktivitas belajar siswa, aspek pengetahuan, aspek sikap, dan aspek keterampilan.

Pada siklus 1 pelaksanaan pembelajaran dengan materi larutan elektrolit dan non-elektrolit dilaksanakan dalam 4 kali pertemuan ( $6 \times 45$ menit). Setiap pertemuan menggunakan model pembelajaran PjBL.

\section{b. Pelaksanaan Tindakan}

Siklus 1 terdiri dari 3 kali pertemuan (4 JP) untuk penyampaian materi dan 1 kali pertemuan (2 JP) untuk kegiatan evaluasi. Kegiatan evaluasi berupa pelaksanaan tes aspek pengetahuan, aspek sikap, dan aspek aktivitas belajar siswa.

Setiap kali pertemuan dilakukan kegiatan apersepsi, orientasi, dan motivasi. Kegiatan apersepsi berupa pertanyaan mendasar yang berkaitan dengan kehidupan sehari-hari. Pertanyaan tersebut merupakan sintaks awal dari model pembelajaran PjBL. Proses pembelajaran dilanjutkan dengan kegiatan diskusi kelompok kemudian dipresentasikan didepan kelas. Pembelajaran ditutup dengan menarik kesimpulan bersamasama dengan guru dan siswa. Rangkuman pelaksanaan tindakan siklus 1 disajikan dalam Tabel 2. 
Tabel 2. Rangkuman Pelaksanaan Tindakan Siklus 1

\begin{tabular}{|c|c|}
\hline Pertemuan & Kegiatan \\
\hline Pertama & $\begin{array}{l}\text { Perencanaan } \\
\text { pembuatan proyek alat } \\
\text { uji elektrolit }\end{array}$ \\
\hline Kedua & $\begin{array}{l}\text { Pelaksanaan praktikum } \\
\text { daya hantar listrik larutan }\end{array}$ \\
\hline Ketiga & $\begin{array}{l}\text { Pembuatan TTS sebagai } \\
\text { media penunjang oleh } \\
\text { siswa }\end{array}$ \\
\hline Keempat & Tes evaluasi siklus 1 \\
\hline
\end{tabular}

Pada pertemuan pertama masih banyak siswa yang sulit melaksanakan model pembelajaran PjBL dikarenakan model pembelajaran tersebut menuntut siswa untuk menemukan konsep pengetahuannya sendiri. Selain itu, pemberian proyek baru pertama kali dilakukan di kelas X MIA 4 SMA Negeri 4 Surakarta, sehingga beberapa siswa belum aktif dalam kegiatan diskusi dan menjawab pertanyaan yang diberikan oleh guru.

Pada pertemuan kedua kegiatan praktikum berkaitan dengan proyek yang telah dibuat oleh siswa, dimana siswa menguji cobakan alat yang telah dibuat pada larutan-larutan yang telah disediakan oleh guru. Kegiatan pada pertemuan kedua hampir sama dengan pertemuan pertama yang membedakan hanya metode yang digunakan yaitu metode diskusi pada pertemuan pertama dan metode praktikum pada pertemuan kedua.

Pertemuan ketiga sama dengan pertemuan pertama yaitu dilakukan kegiatan diskusi, yang membedakan yaitu pada pertemuan ketiga siswa membuat media pembelajaran TTS dengan aturan yang diberikan oleh guru sebagai media untuk mereview kembali materi yang sudah diperoleh dari pertemuan pertama hingga ketiga. Pada pertemuan kedua dan ketiga ini siswa mulai aktif dalam kegiatan diskusi dan tanya jawab. Siswa juga cukup aktif dan percaya diri dalam mempresentasikan hasil diskusi.

\section{c. Observasi Tindakan}

Hasil observasi tindakan menunjukkan bahwa pada pertemuan pertama masih banyak sekali siswa yang belum aktif dalam kegiatan pembelajaran karena siswa masih proses adaptasi dengan model pembelajaran yang digunakan. Pada kegiatan diskusi masih banyak siswa yang hanya diam dan menunggu jawaban dari teman lainnya. Pada pertemuan kedua beberapa siswa terlihat cukup aktif karena metode yang dilakukan berbeda dari pertemuan pertama yaitu praktikum. Rasa ingin tahu siswa yang tinggi menyebabkan siswa ingin ikut terlibat secara langsung dalam kegiatan praktikum. Pada pertemuan ketiga siswa sudah terbiasa dengan model pembelajaran yang digunakan apalagi pada saat kegiatan merancang media pembelajaran TTS, siswa sudah mengetahui terlebih dahulu aturanaturan permainan sehingga tidak membutuhkan waktu yang lama untuk membuat media TTS.

Penilaian aktivitas belajar siswa dilakukan melalui observasi dan angket di akhir siklus1. Angket aktivitas belajar siswa berjumlah 20 soal pertanyaan dimana penilaiannya dikelompokkan dalam kategori sangat aktif (SA), aktif (A), kurang aktif (KA), dan tidak aktif (TA) [9].

Hasil penilaian terhadap aktivtas belajar siswa pada siklus 1 dinyatakan dalam bentuk diagram pie pada Gambar 1.

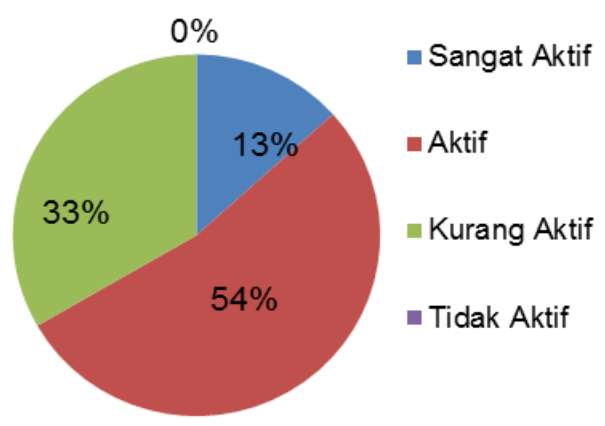

Gambar 1. Diagram Pie Hasil Penilaian Aspek Aktivitas Belajar Siswa Siklus 1

Berdasarkan hasil analisis penilaian aktivitas belajar siswa siklus 1 terdapat 10 siswa yang masuk dalam 
kategori kurang aktif. Hal ini disebabkan karena siswa merasa bingung dengan model pembelajaran yang digunakan sehingga perlu didampingi pada saat proses pembelajaran. Siswa tersebut kurang mendapatkan perhatian yang lebih dari guru dan peneliti. Oleh karena itu penilaian aktivitas belajar siswa siklus 1 belum mencapai target yang ditetapkan yaitu $75 \%$ sehingga perlu dilakukan perbaikan pada siklus 2 .

Hasil penilaian tes aspek pengetahuan pada siklus 1 disajikan dalam bentuk diagram pie pada Gambar 2.

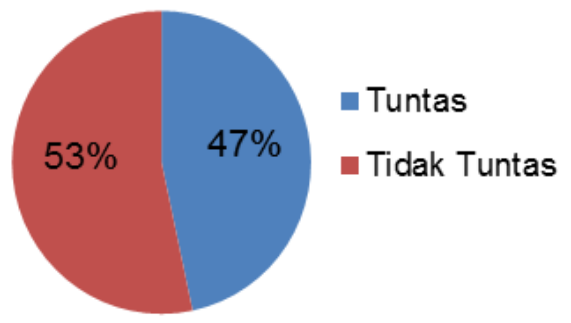

Gambar 2. Diagram Pie Hasil Penilaian Aspek Pengetahuan Siswa Siklus 1

Berdasarkan hasil analisis aspek pengetahuan menunjukkan bahwa terdapat 16 siswa yang belum mencapai ketuntasan. Hal ini disebabkan karena siswa siswa masih bingung menentukan daya hantar listrik senyawa ion dan senyawa kovalen. Siswa membutuhkan pendalaman materi dan soal-soal yang lebih banyak. Pada penilaian aspek pengetahuan ini, terdapat 4 indikator yang belum mencapai target ketuntasan yaitu $75 \%$ dan 1 indikator yang sudah mencapai target.

Tabel 5. Hasil Analisis Ketercapaian Aspek Pengetahuan setiap Indikator pada Siklus 1.

\begin{tabular}{ccc}
\hline IK & Ketercapaian (\%) & $\mathrm{K}$ \\
\hline 1 & 69 & $\mathrm{TT}$ \\
2 & 74 & TT \\
3 & 73 & TT \\
4 & 64 & TT \\
5 & 93 & T \\
\hline
\end{tabular}

Keterangan:

IK : Indikator Kompetensi

K : Kategori

T : :Tercapai

TT : Tidak Tercapai
Penilaian siswa pada aspek sikap terbagi menjadi 4 kategori yaitu sangat baik (SB), baik (B), Cukup (C) dan kurang (K) [10]. Hasil penilaian aspek sikap siklus 1 disajikan dalam bentuk diagram pie pada Gambar 3.

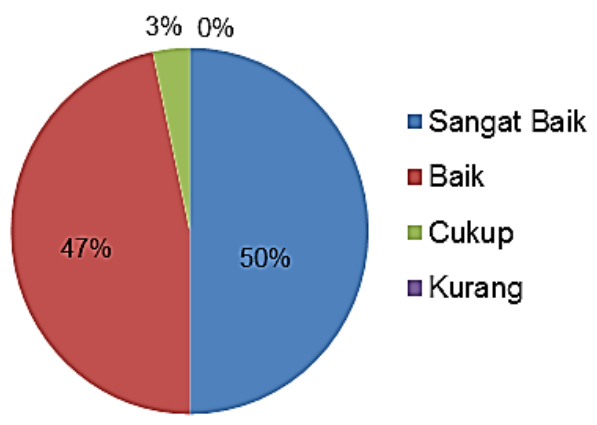

Gambar 3. Diagram Pie Hasil Penilaian Aspek Sikap Siswa Siklus 1

Berdasarkan hasil analisis aspek sikap siswa menunjukkan bahwa telah memenuhi target yang ditetapkan yaitu 29 siswa atau $97 \%$ siswa yang telah mencapai ketuntasan sehingga tidak perlu dilakukan perbaikan pada siklus 2 .

Hasil tes aspek keterampilan pada siklus 1 dapat disajikan dalam bentuk diagram pie pada Gambar 4.

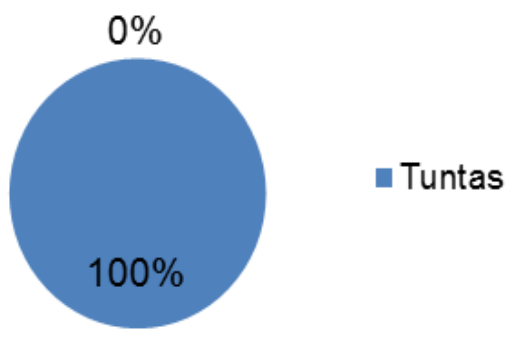

Gambar 4. Diagram Pie Hasil Penilaian Aspek Keterampilan Siswa Siklus 1

Berdasarkan hasil analisis aspek keterampilan siswa menunjukkan bahwa 30 siswa atau $100 \%$ siswa yang telah mencapai ketuntasan sehingga tidak perlu dilakukan perbaikan pada siklus 2 .

\section{d. Refleksi Tindakan}

Hasil analisis siklus 1 menunjukkan bahwa aspek aktivitas belajar dan pengetahuan siswa belum mencapai target sebesar $75 \%$. Terdapat 4 indikator aspek pengetahuan yang belum mencapai target sehingga perlu dilakukan tindakan siklus 2. Tindakan yang dilakukan berfokus pada pemberian soal- 
soal diskusi tentang pendalaman konsep.

\section{Siklus 2}

\section{a. Perencanaan Tindakan}

Pelaksanaan pembelajaran pada siklus 2 hanya difokuskan pada perbaikan terhadap kendala-kendala yang muncul pada siklus 1. Adapaun tindakan-tindakan yang dilakukan antara lain pada saat kegiatan diskusi berlangsung guru lebih banyak berkeliling ke setiap kelompok untuk memastikan siswa sudah paham terhadap materi, memberikan perhatian yang lebih terhadap siswa yang mengalami kesulitan dan belum tercapai ketuntasan pada siklus 1, siswa lebih banyak diberi kesempatan untuk mengemukakan pendapat dan bertanya mengenai materi yang belum dipahami terutama pada siswa yang kurang aktif dalam kegiatan pembelajaran.

Materi dengan indikator-indikator yang belum tuntas pada siklus 1 dilakukan perbaikan pada siklus 2, sedangkan indikator yang telah tuntas tidak dilakukan perbaikan pada siklus 2 .

\section{b. Pelaksanaan Tindakan}

Siklus 2 terdiri dari 1 kali pertemuan (2 JP) untuk penyampaian materi dan 1 kali pertemuan (1 JP) untuk kegiatan evaluasi siklus 2. Kegiatan evaluasi berupa teas apek pengetahuan dan aspek aktivitas belajar siswa.

\section{c. Observasi Tindakan}

Hasil observasi tindakan siklus 2 menunjukkan bahwa banyak siswa yang lebih aktif dan antusias dalam menyelesaikan permasalahan yang diberikan oleh guru. Siswa yang sebelumnya tidak aktif dalam proses pembelajaran terlihat mulai aktif dalam kegiatan diskusi, tanya jawab dan presentasi walaupun masih terdapat 5-6 siswa yang masih mengobrol dengan temannya, namun tetap aktif dalam kegiatan diskusi dan tanya jawab.

Hasil penilaian terhadap aktivtas belajar siswa pada siklus 2 disajikan dalam diagram pie pada Gambar 5.

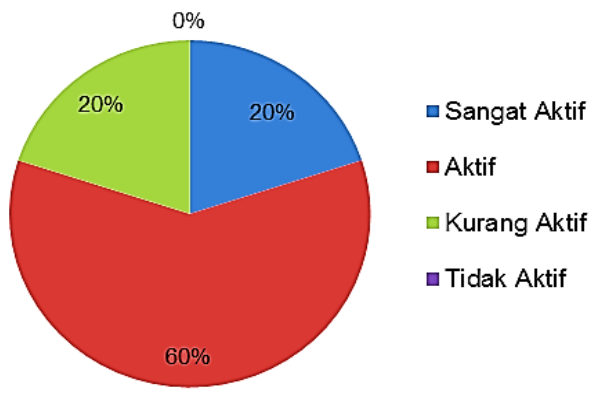

Gambar 5. Diagram Pie Hasil Penilaian Aspek Aktivitas Belajar Siswa Siklus 2

Berdasarkan hasil analisis aspek aktivitas belajar siswa menunjukkan bahwa 24 siswa atau $80 \%$ siswa yang telah mencapai ketuntasan sehingga tidak perlu dilakukan perbaikan pada siklus 3. Hasil tes aspek penge-tahuan pada siklus 2 disajikan dalam bentuk diagram pie pada Gambar 6 .

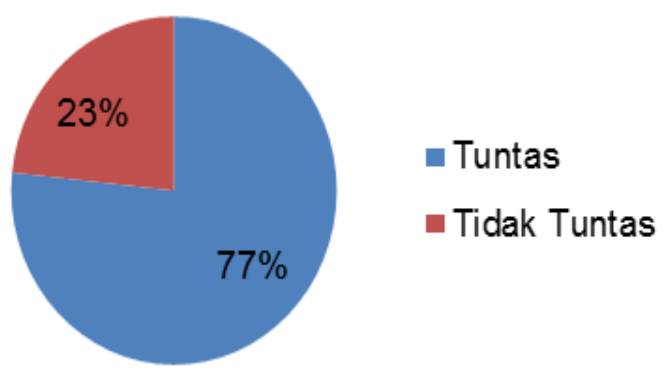

Gambar 6. Diagram Pie Hasil Penilaian Aspek Pengetahuan Siswa Siklus 2

Hasil analisis aspek pengetahuan setiap indikator disajikan dalam Tabel 6.

Tabel 6. Hasil Analisis Ketercapaian Aspek Pengetahuan setiap Indikator pada Siklus 2.

\begin{tabular}{ccc}
\hline IK & Ketercapaian (\%) & $\mathrm{K}$ \\
\hline 1 & 84 & $\mathrm{~T}$ \\
2 & 79 & $\mathrm{~T}$ \\
3 & 78 & $\mathrm{~T}$ \\
4 & 86 & $\mathrm{~T}$ \\
\hline
\end{tabular}

Berdasarkan hasil analisis aspek pengetahuan diperoleh hasil bahwa semua indikator telah mencapai target ketuntasan diatas $75 \%$ sehingga tidak perlu dilakukan perbaikan pada siklus 3 . 


\section{d. Refleksi Tindakan}

Hasil analisis siklus 2 menunjukkan bahwa aspek aktivitas belajar dan pengetahuan siswa telah mencapai target ketuntasan sebesar $75 \%$ siswa yang memperoleh nilai diatas KKM dan hasil aktivitas belajar siswa sebesar $80 \%$ serta aspek pengetahuan sebesar $77 \%$ sehingga penelitian berakhir pada siklus 2.

\section{Perbandingan Tindakan Antar Siklus}

Perbandingan hasil tindakan antar siklus bertujuan untuk mengetahui peningkatan yang terjadi selama tindakan pada siklus 1 dan siklus 2 . Berdasarkan hasil analisis penilaian yang tindakan siklus 1 dan siklus 2, diperoleh perbandingan hasil antar siklus yang ditunjukkan pada Gambar 7.

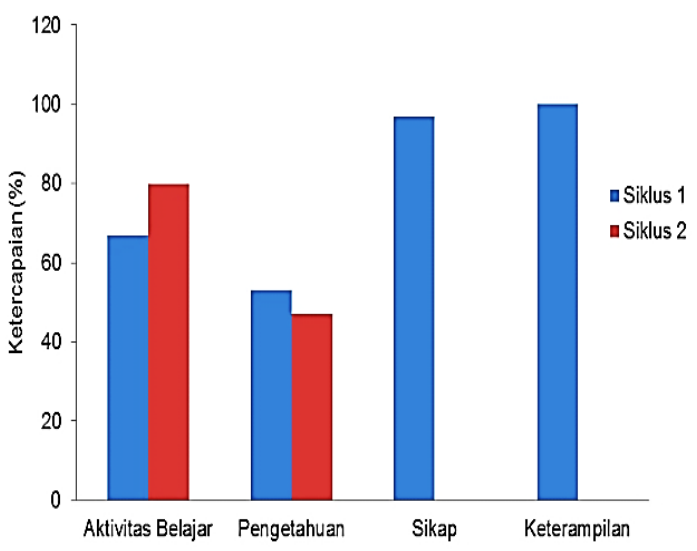

Gambar 7. Perbandingan Hasil Antar Siklus

Gambar 7 menunjukkan peningkatan dari siklus 1 ke siklus 2 pada aspek aktivitas belajar siswa dan pengetahuan yang belum tercapai.Hal ini menunjukkan bahwa penggunaan model pembelajaran Project Base Learning (PjBL) mampu meningkatkan aktivitas belajar dan prestasi belajar siswa pada materi larutan elektrolit dan non-elektrolit kelas $X$ MIA 4 SMA Negeri 4 Surakarta.

\section{KESIMPULAN}

Berdasarkan hasil penelitian yang telah dilakukan, maka dapat diambil kesimpulan bahwa (1) model pembelajaran Project Based Learning (PjBL) dapat meningkatkan aktivitas belajar siswa pada materi Larutan Elektrolit dan Non-elektrolit kelas X MIA 4 SMA Negeri 4 Surakarta tahun pelajaran 2016/2017. (2) model pembelajaran Project Based Learning (PjBL) dapat meningkatkan prestasi belajar siswa pada materi Larutan Elektrolit dan Non-elektrolit kelas $X$ MIA 4 SMA Negeri 4 Surakarta tahun pelajaran 2016/2017.

\section{UCAPAN TERIMA KASIH}

Penelitian ini tidak dapat berjalan lancar tanpa dukungan dari berbagai pihak, untuk itu penulis mengucapkan terima kasih kepada Drs. M. Thoyibun, SH.,MM. selaku kepala sekolah SMA Negeri 4 Surakarta yang telah memberikan izin untuk melakukan penelitian di sekolah tersebut. Terimakasih juga penulis ucapkan kepada Dra. Hartiningsih, M.Pd. selaku guru mata pelajaran kimia yang telah ikut serta dalam pelaksanaan penelitian dan memberikan ijin peneliti untuk melakukan penelitian di dikelas X MIA.

\section{DAFTAR RUJUKAN}

[1] Hasnawati. (2006). Pendekatan Contextual Teaching Learning Hubungannya dengan Evaluasi Pembelajaran. Jurnal Ekonomi \& Pendidikan, 3 (1), 53-62.

[2] Chang, R. (2005). Kimia Dasar: Konsep-konsep Inti. Terj. Muh Abdul Jadir. Jakarta: Erlangga.

[3] Yalcin, A.S., Turgut U., \& Buyukkasap, E. (2009). The Effect of Project Based Learning on Science Undergraduates' Learning of Electricity, Attitude towards Physics and Scientific Process Skills. International Online Journal pf Educational Sciences., 1 (1), 81105.F

[4] Kemendikbud. (2014). Materi Pelatihan Guru Implementasi Kurikulum 2013 Tahun Ajaran 2014/2015: Mata Pelajaran IPA SMP/MTs. Jakarta: Kementrian Pendidikan dan Kebudayaan. 
[5] Raines, D.A. (2010). An innovation to facilitate student engagement and learning: Crossword puzzlez in the classroom. Teaching and Learning in Nursing, 5, 85-90.

[6] Arikunto, S., Suhardjono \& Supardi. (2007). Penelitian Tindakan Kelas. Jakarta: Bumi Antariksa.

[8] Miles, M.B., \& Huberman, A.M. (2007). Analisis Data Kualitatif, Buku Sumber Tentang MetodeMetode Baru. Jakarta: Universitas Indonesia Press.
[9] Sugiyono. (2013). Metode Penelitian Pendidikan (Pendidikan Kuantitatif, Kualitatif, dan $R \& D)$. Bandung: Alfabeta.

[10] Permendikbud. (2014). Nomor 104 Tahun 2014 Tentang Penilaian Hasil Belajar oleh Pendidik pada Pendidikan Dasar dan Pendidikan Menengah. Jakarta: Kementrian Pendidikan dan Kebudayaan RI. 